\title{
Empowerment of Love for Jane Austen's Females: A Case of Creativity in Familiarity
}

\author{
Assia Alhasan \\ Institute of Languages, University of Tabuk \\ Tabuk, Saudi Arabia \\ Corresponding author \\ Noritah Omar \\ Department of English \\ Faculty of Modern Languages and Communication \\ University Putra Malaysia, Serdang, Malaysia,
}

\begin{abstract}
:
The goal of this qualitative study is to explore unfamiliar concepts presented in familiar contexts in Austen's Pride and Prejudice (1813) and Mansfield Park (1814). Also, it intends to examine Austen's creativity in unfamiliar concepts such as women's freedom of choice and education from a feminist perspective. This study is significant for shedding light on the empowerment of love decision, females' self-awareness and women's voice presented in conventional systems. In addition, it will help feminists to figure out the feminism issues reflected in Austen's work. Further, this study addresses the question of unfamiliar concepts in Austen's familiar contexts and identify the impact of decision making on women's equality. The researcher uses textual analysis to discuss main themes and address research questions. The findings of the study show that Austen best novels preached out women's emancipation of so-called marriage-market. Also, the result indicates that women of her time postulated love in marriage for achieving self- recognition and self-esteem through creative technique of familiarizing unfamiliar concepts. Therefore, it introduces new thread to Austen studies by examining how Austen familiarized her readers unconsciously with modern concepts at the late $18^{\text {th }}$ century in societal and cultural respects. This study recommends that further investigations be conducted in this regard.
\end{abstract}

Key words: familiarity, unfamiliarity, empowerment, intelligent love, mind liberty

Cite as: Alhasan, A., \& Omar, N. (2020). Empowerment of Love for Jane Austen's Females: A Case of Creativity in Familiarity. Arab World English Journal for Translation \& Literary Studies 4 (4) 131-150. DOI: http://dx.doi.org/10.24093/awejtls/vol4no4.10 


\section{Introduction:}

Creativity in familiarity is a common skill that is known by many scholars and authors in the field of feminism. In conventional repertoire, creative authors present their unamplified opinions in exciting extents over a complete familiarity to endorse accounts of unfamiliar concepts such as empowerment of love, decency, unfaithfulness, manipulation, freedom of choice, education and sacrifice (Marek, 2018). The outstanding of familiarity characteristics provides sets with a considerable number of personnel live at a point of time.

Austen, is a writer acknowledged for her extraordinarily genuine stories that reward common personal experiences and define unfamiliar concepts in familiar context in the context of the English powerful aristocracy of late $18^{\text {th }}$ and early $19^{\text {th }}$ centuries a comparatively protected, composed dominion of existence. Possibly, it is this apparent inconsistency that barred the use of Austen's fiction in many settings. Currently, appreciated in academic and prevalent settings comparable in sites as diverse in both in western and eastern cultures, Austen is one of the most renowned novelists worldwide and on the edge of a more exhaustive exemplification in many contexts (Shultz, 2018).

All over her novels, thoughtful analysis is related to knowledgeable and ethical improvement. The degree to which the novels reproduce feminist issues has been expansively argued by researchers; most opponents approve that the novels best part how some female charismas take responsibility of their own realms, whilst others are restricted, physically, emotionally and spiritually. Nearly all Austen's works search the unjustifiable financial situation in which women of the late $18^{\text {th }}$ and early $19^{\text {th }}$ centuries established their own worlds (Sunalini \& Kumari, 2017). Austen's novels have differently been defined as constitutionally conventional and liberal. For instance, one aspect of criticism argues that her heroines empower the prevailing social construction through their devotion to responsibility and sacrifice of their own desires. Another claims that Austen's uncertainty of patriarchal ruling "other", demonstrated by her sarcastic tenor. Within her consideration of political themes by the upper class, Austen discusses issues relating to unfamiliarity of concepts, particularly in familiar contexts (Worsley, 2017).

Austen $(1775$ - 1817) is well-known for her romantic novels based on the theme of love and marriage. She created female characters who are obsessed with marriage for security and wealth. Implicitly and wittily Austen dealt with this societal matter of the early nineteenth century to uncover the patriarchal dominance of her time. Since women were deprived of heritage after their parent's death and with the limited proper chance of work to earn money, they were obliged to find a wealthy match regardless of their mates' mentality or behavior. Austen as a realist writer reflected the life of the 'common place' in her era. The so-called "marriage market" (Marrero, 2013) which was developed earlier to Austen's publications had a transitional effect on the society ideology in general and on women's status in particular. Therefore, women in Austen's time, literally, were in-between the hammer and the anvil. Similarly, her female characters struggled out not to compromise their freedom of choice over security and wealth. Miss Austen addressed this notion in one of her letters to her niece Miss Fanny Knight saying: "anything is to be preferred or endured rather than marrying without affection [...]" (qtd in Lanski; 1969, p. 99). Austen in her 
six novels focused on marriage customs, however, presenting her own thoughts of what good marriage is to be.

Austen was known as a woman of education who valued marriage as a fundamental requirement for family. Therefore, her perception of good marriage was based on mutual understanding and morals. That is why may be Austen herself rejected a proposal when she could not find her equivalent match and preferred to remain an 'old maid' though. As quoted in one of her novels: "Give a girl an education, and introduce her properly into the world, and ten to one but she has the means of settling well, without farther expense to anybody" (Austen, 1814; p. 5). This indicates Austen's perception of modernity to women's own rights in getting education and independency. Hence, Austen's main contribution to feminism was in giving women a capacity for individual, adult, moral choice and perception, highlighting the role of women in a family, and motivating women to act independently of men and patriarchal interests (Evans, 1986).

In Pride and Prejudice (1813), Austen deliberately connected the theme of love with intellect. A woman of intellect for Austen would never say 'Yes' for a marriage without love. Those women who would never say 'No' to mercenary marriages like Charlotte claim that happiness in marriage is a matter of chance, away to denounce the idea of love as a condition for a happy marriage. However, Austen played a strategical game with most of her female characters who maneuvered not to announce their feelings till about the end of her novels, in evidence that love in Austen was not just a matter of affection but rather a matter of mind's affection. Lovers for Austen do not fall in love at first sight. That is why Elizabeth and Fanny select persons agreeable to their temperament and personality. The real object of marriage is not home and house -keeping, it is rather intellectual and emotional association between a husband and a wife (Sundari, 2015).

This paper focuses on the creativity of Austen in exploiting familiar concepts to convey unfamiliar concepts, and to show the impact of intelligent love on women, during the late eighteenth and nineteenth centuries, to exercise power and freedom of choice in their pursuit for gender equality and explore the unfamiliar concepts presented in familiar contexts in Pride and Prejudice and Mansfield Park novels. In this regard, this study aims at examining how love empowers women in Austen's both novels; analyzing how love empowers women and investigating the impact of decision making on women's equality for Austen's females.

\section{Literature Review:}

Austen (1775-1817), as a renowned female writer of the nineteenth century has offered critics and feminist in particular a chance to discuss her premature feminism views. A bulk of studies investigated her six novels with their different themes in order to highlight the impact of Austen's fiction on women status in the English communities (Shukurova et al., 2020).

Alkubaisi (2020) argued that Austen's works still affect readers till now due to her unexpected modernity and actuality. Austen's supremacy among her contemporary is attributed to the modern propositions she discussed in her works, such as realism, feminism, morality. The depth in her novels is exploited through structuring social mechanics around the concept of ideal 
family communities to present a pioneering model to guide others especially educated minds in pursuit to a better future. For instance, Austen offers a woman's standpoint towards a patriarchal society through the lens of Romanticism, therefore, even though her female protagonists break social constraints are still celebrated in literary history and they are rewarded with a triumph, a happy marriage.

Austen manifested the conflict of human being faculties: reason and passion. In Pride and Prejudice lovers are striving for love and affection under the pressures of manners and mannerisms of their societies. Despite previous studies on the concepts of love and marriage in this novel, the researchers conducted a comparative study of Plato's concept of love that is featured in a different manner of realism as former studies portray love in an ideal form. This study introduced a new perspective to Austen studies by examining Platonic concepts of love in Pride and Prejudice. The study showed that although Austen is Platonic in her approach to love, she is distinguished in confining love to decorum concealed by social relationships which is due to the fact that the Victorian's epoch makes priority to the practice of love in real context over intellectual concern for what it might mean or might not (Sha'bäni, Harehdasht, and Naseri, 2019).

Marek (2018) investigated the decision-making components of Austen's six major novels with his reference to Michael Chew's argument that Austen was a predecessor of game theory. She provided a plethora of strategic situations in the mating process; one example of her strategic thinking shown in Pride and Prejudice is Mrs. Bennett's $2 \times 2$ strategic game which is equivalent to a decision problem. Interestingly, "choice" appears in game-theoretic models in a normative context especially when restricting choices. Marek argues that for Austen emotions can lead to bad decisions, yet sometimes can be managed strategically. Therefore, Austen's heroes take time to calm down and make a proper decision. In consistence with rational thinking, (Asokkumar, 2014) claims that Austen was a woman of reason more than emotion. She describes her country middle class by depicting different aspects of love and marriage with distrust to emotions. Her characters go through self-delusion, disillusionment, reconciliation, awakening, and then empowerment in a process of development. According to (Kearney, 1990) reason for Austen is based on intellects.

Though, Austen in her novel Pride and Prejudice (1813) showed the different position of women and their social expectations related to marriage. The minor characters in the novel that represent the majority of women in the nineteenth century who did not have much choice to decide their future due to the patriarchal role in shaping women's lives. However, Austen presented the protagonist (Jane Fairfax) of this novel as a unique response to those expectations that resembles the strong women who are ready to do anything in the name of love. Austen was known as an intelligent writer who would not present her opposing thinking overtly in a conservative society, nonetheless the protagonist in her novel goes against the stream in her choice regardless of the social expectations, setting a successful example of how love empowers women to decide their lives (Cristina, 2019). Peltason (2015) also confirmed that Austen's point of view of romantic love measures her commitment to represent love as a property of full, active and distinguishing mind.

Arab World English Journal for Translation \& Literary Studies 
That is, women equality, empowerment, and freedom to make choices are instrumental in the decision-making process. Swirsky and Angelone (2016) stated that. In addition, the exposure to feminism, both through education and personal role models, has also led to their selfidentification. Therefore, there is a need of exposure to feminist beliefs through education, strong feminist role models, and awareness of gender discrimination to correct the social gender imbalance. Similarly, this contributes to Austen's own beliefs about the necessity of education for women to be as equal as men and acquire independency as (Nandana,2012) showed that women of Austen's time lacked proper education and consequently had less professional status, therefore, they sought for matrimony to secure their lives. Austen with her insightful mind described an educational system that does not worth a great deal if it teaches young people how to make a living but does not teach them how to make a life.

Sundari (2015) pointed out that love in Austen is a central theme in all her novels. Austen considered that the human life is based on love and marriage, therefore love occupies a larger social context in her fiction. Her heroines are sensible lovers; they admire their lovers' intelligence rather than their good looks. Austen wrote as a woman about women, so she had a practical view of life and marriage in her fiction. Hence, Dangel et al., (2015) showed that Austen's female characters are challenged through courtship to prove their independence and empowerment when they search for a man that they could marry. It is asserted that Austen's attempts to empower women by depicting her female mating strategy, particularly with the absence of their parents' guidance.

\section{Research Methods and Design:}

This paper provides the practicality of qualitative methods in relation to literature mainly when an explicit hypothesis can be tested and validated. The research was designed to examine Austen's novels in terms of empowerment of love a case of creativity in familiarity and unfamiliarity. Also, this study design was selected to establish whether the concluding unfamiliar concepts in familiar contexts are essentially being treated by the writer as fortunate and pleasant events. To address research questions, the researcher used a method to measure the familiarity of unfamiliar concepts.

The analysis of Pride and Prejudice (1813) and Mansfield Park (1814) also establishes the techniques in which plot and setting shape is formulated, and recommends many statistics to be used in the assessment of the existence of unfamiliar concepts in familiar context as aspects of love empowerment in Austen's novels. These two novels are old British versions available, referring to late $18^{\text {th }}$ and early $19^{\text {th }}$ centuries a comparatively protected, composed dominion of existence. The texts of Austen's novels of Pride and Prejudice (1813) and Mansfield Park (1814) were downloaded from Google Scholars sites 2020. The text of each novel was scored by looking at themes that emerge such as intelligent love, mind liberty, unfamiliarity, familiarity and empowerment.

\section{Feminism Trends in Austen}

Austen (1775-1817), is one of the best well-known writers of the western canon. The debate over her standpoint whether she is a feminist writer, or a restrained feminist has varied among 
researchers (Swirsky \& Angelone, 2016). Undoubtedly, Austen was affected by writers like Mary Wollstonecraft, Samuel Johnson, Samuel Richardson, and Oliver Goldsmith. From women novel writers she admired Fanny Burney and Maria Edgeworth.

Austen was not considered a radical writer in one sense that she was more sensible rather than being 'unladylike' as the radicals were decided during the $18^{\text {th }}$ and $19^{\text {th }}$ centuries (Caffery, 1997). However, in accord to the main goal of the feminism ideologies of improving women's social status through working toward equality and against women's oppression and devaluation (Swirsky \& Angelone, 2016), Austen used the typical marriage plot by granting her heroines greater autonomy and happiness through marriage between equal partners. Conventionally, the predominantly male society has made marriage the primary aspiration of its female members (Alwadhaf \& Omar, 2011, p. 115). As opposed to this dominant notion of patriarchal societies Austen's females ironically reverse the traditional pursuit of marriage for women to make it the aspiration of men. In one instance, it's Mr. Crawford in Mansfield Park who seeks Fany's consent for marriage. In addition, Austen questions the domination of men by showing that men as women make errors (Caffery, 1997). Assuming that for a writer like Austen at the late $18^{\text {th }}$ century in a regency society where women are prepared for "domesticity and men for leadership, with the minimum of options to reveal her thoughts, Austen finds that it is either ways to be rejected or to maneuver to get her points across. Otherwise, how can one interpret her consistent emphasis through her six novels on the conflict between mercenary marriage and affective individualism (Hall, 2009).

Austen was a reactionary and revolutionary; taking out the exclusion of women from political power where ever possible, her reaction in sense of order to the revolutions of France and America. Her views of the accomplished woman acquired from Mary Wollstonecraft's versions (Durrani, 2019). In feminism, the main concerns are education and the social position of women. Books and libraries in Mansfield Park and Pride and Prejudice used to show characters and social expectations. Fanny's upstairs room at Portsmouth becomes more like a private library. Austen explains how it becomes for Fanny; "There were none in her father's house; but wealth is luxurious and daring---and some of her's [sic] found its way to a circulating library" (Austen, 1814, p.313). The use of circulating libraries refers to Fanny's independence of mind (Marzec, 2014). Mainly, libraries appeared to be possessed by men like Mr. Bennett and Mr. Thomas, women like Fanny and Elizabeth possess number of books and they were even allowed at certain times to access the library. During that period Men used to read loudly in the communal gatherings for reading. Women of a higher social rank have good education like Mr. Bingley's sisters, and this gives them more self-esteem.

Fanny and Elizabeth in accordance educate themselves through reading in similar way to Austen's education. Reading which is a primacy for study in Austen is allowed for intellectual discussions to show the superiority of mind. Even though she was not a radical writer, but she intended to change through improvement. Instead of mercenary marriage she urged for compatible marriage and independency for women away from the dominance of men. From a feminism

Arab World English Journal for Translation \& Literary Studies 
standpoint, it is cut clear that Austen's thoughts and aspirations for more women's rights and freedom of choice are genuinely feminist.

\section{Discussion:}

Overall Creativity in Unfamiliarity and Familiarity in Austen's Novels

Austen is one of the greatest realistic writers in the English Literature in the $19^{\text {th }}$ century. The main themes of all her novels are love and marriage. Her narratives concern with the issues of her society with a full description for the common place. Austen presented familiar romantic narratives that pleased her readers since then. She presented familiarity as the description of commonplace at her time by creating interesting daily incidents (Smith, 1890). On the other hand, she delineated unfamiliarity as unexpected thoughts that open intellect readers' minds to modern assumptions about justice, women's rights, education, intellectualism, and financial independence as main pillars for a modern society.

Her professionalism is manifested in shaping unfamiliar thoughts within familiar contexts. At the time of Austen's era, it was rare to find a writer who dares to write about gender issues. Most work had few or little female characters in an implication to the triviality of the females in the society at that time (Shultz, 2018). Nonetheless, Austen's novels deliberately are crowded with female characters. The most common type of women that Austen exposed is the conventional women that adhere to the norms of the society and still follow the same means of their ancestors to improve their lives through marriage without giving themselves a chance to think differently. While, the exceptional type that is presented with few numbers of women in each novel like Elizabeth, Jane, and Fanny who resist the mercenary marriage and take their decisions on their own. Austen in Mansfield Park maintains that improvement and guidance begin within oneself, otherwise it is less likely to make a change, as she states: "We have all a better guide in ourselves, if we would attend to it, than any other person can be"(Austen, 1814, p.372).

Yet, Austen presented an unsure female character who longs for love and still abides to the market marriage like Miss Mary Crawford who renounced her love to Edmund just when she knew that he intends to become a clergyman because of her ambitions to wealth and high rank in society. This might be a good justification why Austen stood firm on her opinion for the ending in Mansfield Park while her sister Cassandra wanted Mary to be married to Edmund and Fanny to a wealthy man like Henry (Worsley, 2017). This proves that Austen gives happy endings only for strong women of high morals who would not change their positions for materialistic matters. Also, the familiar ending that Austen disapproved is that a good reward for a poor woman is to marry a wealthy man. To the contrary, her unfamiliar reward is to marry her soul mate. In addition, Austen with the happy-ever-after ending, she confirms a universal theme of marriage as the ultimate goal for a woman.

But nevertheless, it was not her own goal. Thinking differently, Austen asserts that marriage is not everything for a woman, she comments comically when she was in her sickbed to her sister, Cassandra: "She died a successful author, her lifelong ambition fulfilled". (Hynes, 2017, p.3). Despite the fact that her novels end up with marriage which was part of the realistic life, 
Austen encourages her female nieces to postpone childbirth a little later in their lives so that they will not be exhausted early. Therefore, one of her techniques to convince her readers of the unconventional thoughts was by rewarding her exceptional females like Elizabeth and Fanny for their exceptional standpoints with a happy ending (Mondadori, 2018).

Austen realistic narrative depicts social life with illumination to the most common themes of 'love and marriage' at that time. This familiarity of those themes worked well and received acceptance by her readers. Nonetheless, Austen succeeded to deliver her lessons of modern concepts of love and marriage. Austen opposed the market marriage and she even emphasized the significance of love based on mutual understanding and maturity. Part of Austen's (1814) great belief of the necessity of education for women in preparation for a good life as quoted in Mansfield Park, "give a girl an education, and introduce her properly into the world, and ten to one but she has the means of settling well, without farther expense to anybody" (Austen, 1814, p.477). Austen, as in all her six novels provides a comprehensive interpretation of what a woman's education should be. She emphasizes core principles, such as self-recognition, self- improvement, selfindependence, and self-esteem. This is due to her awareness of the opportunities that education can offer for a woman.

Considerably, her novels as much as they include amusement, they provide instructive lessons. Austen realized that the compatible relation between education and profit enhances the financial freedom for women. Austen asserts women's freedom conditioned by financial independency when she declares this point in Mansfield Park on Fanny's tongue, she states: "A large income is the best recipe for happiness I ever heard of" (Austen, 1814, p171). As a writer, she supported herself, her mother, and her sister by publishing novels (Marzec, 2014). Although Austen provides a social commentary based on the plot of marriage, she describes education as a fundamental requirement for a better life through marriage (McElligott, 79-98). Mr. Bennett, a man of education who spent most of his time among books in his library realizing the gap of education between him and his wife would not spare such an advice to his own daughter of what should it be like the relation between a husband and a wife as he states:

I know that you could be neither happy nor respectable, unless you truly esteemed your husband; unless you looked up to him as a superior. Your lively talents would place you in the greatest danger in an unequal marriage ... My child, let me not have the grief of seeing you unable to respect your partner in life" (Austen, 1813, p.254).

If Austen was not a writer, she could have been a successful teacher; in both novels her educative approach shows how her heroes and heroines learn how to recognize their faults and weakness and improve them. They learn how to affect others and be affected. In Mansfield Park, Austen exploited the familiarity of the literary traditions about public ideas and events to present her variation of her own improvement in organizing, drastic landscape (Smith, 1994). "If William does come to Mansfield, I hope you may be able to convince him that the many years which have passed since you parted, have not been spent on your side entirely without improvement"(Austen, 1814, p.33). Miss Fanny Price is presented at the beginning as a calm, shy, decent woman who managed 
through the narrative to become more confident and stronger despite the disparity of the two different classes she lived in, that most probably would have affected her psychology negatively. Thus, the expected behavior for Miss Fanny is to marry a wealthy man who could help her to improve her life, however, the unexpected consequence is that Fanny herself is the one who improved to be stronger physically and intellectually.

Again, Austen declares improvement in the state of wellbeing not in possession of fortune. Indirectly, this entails that women's real improvement is in their self- improvement. Even for strong female characters like Miss Bennett, still Austen deals with their flaws like vanity and self -conceit that as flaws of mind that block insights and lead to incorrect judgement referring to Miss Elizabeth misjudging Mr. Wickham and Mr. Darcy. When Elizabeth recognized her faults, saying: " I who prided myself on my discernment! I, who have valued myself on my abilities! How humiliating is this discovery! - Yet, how just a humiliation! Till this moment, I never knew myself " (Austen, 1814, p. 20). Clearly, even for one of the best heroines in Austen's novels, Austen assumes that perfection does not exist, and that improvement is a continuous process that a man and a woman should seek.

Austen's brilliance is manifested in her ability to make an approximation between reality and imagination, also to transform constrains and customs of a society to the tenderness of Art (Rubin, 1988). Commonly love is presented with a pivot focus that revolves around emotions and meekness, love in Austen revolves around rationality, and affection is driven by the personality and mentality of the lover. Mr. Darcy was fascinated with Elizabeth's strong personality and oppositional nature. Similarly, Elizabeth argues Charlotte about her sister's love to Mr. Bingley that, "This is not quite enough to make her understand his character"(Austen, 1813, p. 18). She relates love to mind, it does not happen at first sight. Austen postulates that love happens when a woman has an enough understanding of her mate's personality.

Creativity in Austen is mastered through the combination of simplicity and complexity in her novels, (Webber, 2017). As a writer, she is known for being realistic and romantic. Her novels are classic, however, apt to modernism. She presents universal themes with a holistic social commentary, yet she sparks revolutionary thoughts of women rights of education, decision making, equality, and rationality. With no doubt, Austen keps a huge balance in the aesthetics, language, and style of her novels that enabled her to hold the stick from the middle. Austen breaks the social norms by her crafty females who flirt and seduce as well as men do within the restrictive conditions of their society. Women are active agents who would compete to access and win their desirable men (Kruger, Fisher, Strout, Lewis \&Wehbe, 2014, Massiha \&Omar, 2013).

She does not portray women as angelic females, but rather as naughty, selfish, and selfconceited as in reality. Therefore, it was argued that Austen was more likely read by men, although she appeals to more concerns of women. This might justify why Austen is for all readers as Weber argued.

Arab World English Journal for Translation \& Literary Studies 
Wollstonecraft quoted "I do not wish them [women] to have power over men; but over themselves". In the same manner, Austen seeks to empower women over themselves in first hand. A woman of her intellect keeps the calls out for modernity in consistence within the limits of her conservative community and revolutionary insights, using the constraints of her domestic settings to her benefit (Moe, 2016). Very intelligently among all other typical models of her female characters, there is this female character like Elizabeth Bennet or Fanny Price who would choose to oppose the normal norms and customs unexpectedly. In the marriage-plot, the heroines' desire to exercise power is driven from their desire to choose whom to marry not only to have a man (Toner, 2020). Elizabeth and Fanny similarly reject getting married to two wealthy men while they are not in a state to decide upon their senses under the regency of a patriarchal society in the late of 18 th century.

The theme of pride in Pride and Prejudice (1813) is used as an equivalent to superiority not just over the other but rather over one's own passions and temper. Elizabeth's trait being a sarcastic persona gives her the strength not to be affected by others' insult like when Mr. Darcy expressed his view in Ms. Bennett: "She is tolerable; but not handsome enough to tempt me." (Austen, 1813, p.9). The power that might Austen had wished women to possess is to have a strong standpoint and not to be vulnerable as they are expected. Ms. Bennet's reaction is an exemplary for all women to be overt and make fun of whatever they dismay, like the way Lizzy did when she told her friends of the story with Great Spirit. Furthermore, the comparison that Austen implicitly draws the reader's attention to between the pride of a woman and the pride of a man reinforces the female's character and superiority. Miss Lucas attributed Mr. Darcy's pride to his family status and wealth justifying that when she said: "If I may so express it, he has right to be proud." (Austen, 1813, p.15). However, Elizabeth' pride as Austen overtly declares on Mary's tongue that, "Pride relates more to our opinion of ourselves." This justifies that Elizabeth's pride is due to her selfrecognition which is an intrinsic source of someone's personality, to the contrary of Mr. Darcy's which is attributed to an extrinsic source and this empowers a woman with no wealth to be proud of being who she is as Elizabeth stated to Miss Lucas: "and I could easily forgive his pride, if he had not mortified mine" (Austen, 1813, p.16). By this declaration, Austen gives one important lesson to women that, a woman of a strong belief of herself can make her a peer to a male if not superior.

Austen was known as a realist novelist. A woman of her brilliance used realism to reinforce the power of women. What would empower a woman more than being aware of her reality? Jane Elizabeth's sister finds that being asked twice to dance by Mr. Darcy at the ball is a compliment while Elizabeth's awareness of her sister's beauty does not put her at surprise for his compliments. Here, she made her remark to her sister: "What could be more natural than his asking you again? He could not help seeing that you were five times as pretty as every other woman in the room." (Austen, 1813, p.11). Thus, genre of Austen's novels is a mix of realism and romance. Radu (2013).

However, she was a woman of reason as argued by (Asokkumar, 2014) who wrote out of her experiences and domestic observations. This supports viewing her as a realist novelist by researchers like Tauchert (2003), Caffery (1997), and Dole (2007). What makes Austen's writing 
pleasant for even modern readers is that she puts facts in an understandable, rational, and natural pattern (Aron, 2014). The same for her heroines' improvement that both Elizabeth and Fanny experienced through their mindfulness and rationality that they come to recognize their won senses eventually. They, at first, resist all temptations to marry wealthy men and secure their own lives. Austen contends how does rationality empower her female characters over men when Mr. Crawford expresses his disappointment for being rejected by Fanny saying that she is killing him by rejecting his proposal, but Fanny asserts that; No man dies of love but on the stage, Mr. Crawford. (Austen, 1814, p.277).

\section{The Concept of Love}

The concept of love that Austen views for her protagonists enables them to evaluate their own entities at a level where they would not compromise for their morals and integrity. Austen's Love would lead to enlightenment not blindness, truth not illusion. Although Elizabeth realized her misconceptions of Mr. Darcy, still being cautious and not to step forward unless being very certain of one's own steps, puts her in a centrism that gives her more power over herself. As opposed to rationality, Austen presents another example where the power of irrational love would lead to illusion and blindness. Lydia Elizabeth's second youngest sister apparently love empowered her to act in a repulsive manner due to her innocent affections to Mr. Wickham and decided to violate the norms of her society and run away with Mr. Wickham causing herself and her family bad reputation. Austen does not perceive love as a means of subversion, therefore, she keeps her paces within the society's norms and customs. Love and Marriage are supposed to construct good families and societies but not to ruin them. Lesson given; not to accept a suitor against your own will, yet acceptance should occur with a deep consideration to the family and society's regulations.

Love is a main theme of all Austen's novels not only in a sense of a key element of a romantic novel or a repetitive pattern of entertainment. It is basically dealing with a universal theme that most human relations revolve around. However, Austen in purpose presents love as a catalyst that affects the type of relationships and changes the cartography of a society when it merges two different classes of a society together. Love in Austen appears to be a source of power for both women and men that enables them to overcome barriers of social constrains. Mr. Darcy in Pride and Prejudice and Mr. Edmund in Mansfield Park remain in a state of denial to their love due to the pressures of their gentry's class. For instance, as quoted in Pride and Prejudice "Mr. Darcy had never been as bewitched by any woman as he was by her. He really believed that, were it not for the inferiority of her connections, he should be in some danger." (Austen, 1813, p.45).

This explains why his behavior was, for Elizabeth, a kind of a mixture of sweetness and archness. Clearly, he struggles the baselines of his class and affections. In Mansfield Park, Fanny rejected the proposal of Mr. Crawford simply because she does not love him: " I- I cannot like him, sir, well enough to marry him" (Austen, 1814, p. 85). Austen believes that not being in love is a good reason to reject a suitor, to the contrary of common norms at that time. Marriage requires a mutual understanding and equivalent peers to start this martial relationship. Whereas, Miss Marry Crawford's ambitions for wealth outweighs her affections to Edmund. 
Based on her misconceptions for what a successful marriage is, Mary changed her plans towards Edmund because it appears to her that he plans to be a clergyman which does not suit her materialistic ambitions. Austen presents both ladies of Mansfield Park; Miss Fanny and Miss Mary as intelligent women, however she gives the credit to Fanny's intelligence since it is grounded to morality and true emotions. Those two merits in a personality lead to happy endings and felicity unlike self-centeredness and greed that end up with shame and regret.

\section{Intelligent Love and Mind Liberty}

Luxemburg (1968) states that freedom is "always the freedom of who thinks differently". The most prominent concept that any estranged reader can recognize in Austen's novel that she consistently alludes to mind liberty of any deficiency or vanity. Austen considers these defects in a woman's mind that narrows her sight and turn her down, in an instance Lydia's story in Pride and Prejudice and Maria in Mansfield Park. She even considers such a mind a vacant one. Trilling (1957) argued that Austen advocated for 'intelligent love'; according to a pedagogical relationship that exists upon true and mutual relationship. In Pride and Prejudice and Mansfield Park love is presented in two forms; irrational love that is out of mere emotions and rational love based on self -awareness and maturity. The former love is unapproved to Austen and it is always doomed with unhappy endings, while the latter is encouraged and rewarded and has a pedagogical dimension (Radu, 2013). Therefore, she shows out the depth of intellectual freedom when she describes Mary Crawford in Mansfield Park, she says:

"Mary had none of Fany's delicacy of taste, of mind, of feeling. She saw nature, inanimate nature, with little observation; her attention was all for men and women, her talents for light and lively" (Austen, 1814, p. 104).

This kind of love that is fancied with morals and personality which occurs after thorough observation and deep understanding of the inner possessions of a mate opposing to instant love sparked by good looks and materialistic matters. Intelligent love puts the thinking area of the head in control unlike emotional love that fixates on one object of affection and dominates the logical thinking of the brain (Patil, 2014). Therefore, it sets the mind free of short- sightedness and counterfeit. Austen presents a mature state of love that protects a lover to commit any misbehavior which contradicts with the community's customs and culture.

Elizabeth summaries the cause of irrationality in a pedagogical framework, referring to her sister Lydia's little mindedness: "she has been never taught to think on serious subjects; and for the last half year, nay, for a twelvemonth she has been given up to nothing but amusement and vanity" (Austen, 1813, p. 245). The right architecture of mind for Austen is through good education, guidance, and authentic situations away from amusement and triviality. Elizabeth and Jane being the eldest daughters of Mr. Bennett have been given more attention and their good education enabled them to understand people and be aware of their behaviors as they read books and analyze them. Austen succeeded in connecting good education to logical thinking that leads to the right morals. Austen as a moralist writer reveals that her heroes and heroines' moral traits make them mature enough to start a relationship (Feesenbecker, 2011). Lydia was young with no

Arab World English Journal for Translation \& Literary Studies 
good education or a direct guidance, therefore, her failure to recognize the consequences of her relationship with Mr. Wickham was inevitable.

\section{Freedom of Choice a Call for Women's Equality}

Decision making resembles strength and rationality in order to avoid errors or mischievous consequences. Austen documented the difficulty of making a choice for women at her time owing that to the social constraints and lack of education which disabled them to choose or even form a preference of complex objects (Kaminski, 2018). The difficulty of making a choice might be a reasonable justification why most women would say yes for marriage. It is always easier to say 'yes', but it is not for a 'no'. Those who would say 'no' are able to consider other alternatives and their possible outcomes.

Therefore, Austen with her insightful thinking presented exceptional women who make their own decisions as equivalent to their counterparts. For instance, Elizabeth turn down Darcy's proposal in suggestion for a woman's equity to accept or reject, albeit, her social and economic status. Fanny rejects Mr. Henry's proposal and Mr. Thomas does not understand why Fanny would reject such a charming wealthy man, whereas a woman of Fanny's intellect considers the morals and behaviors of a man more than his good looks and wealth. Decision based on deep thinking and observations lead to secure and safety to the contrary of decisions made by emotions without reason that lead to bad results as Lydia and Maria. Austen relates bad decisions to lack of knowledge and reason, therefore, the best way to be able to take the right decision is to be welleducated along with the family guidance. Elizabeth blames her parents for not giving Lydia the guidance and leaves her instead venturing on her own.

Education for a woman is not just a need it is a must if they want to recognize their abilities and chances. The discrepancy made by inequality of education between men and women had made its effect on women's prospects. Austen herself was educated at home while her brothers went to school. Despite Elizabeth's social inferiority, Mr. Darcy being a well- educated man realized her intelligence and distinctive nature that makes him attached to her. Austen implicitly hints to the necessity of gender equality in martial decisions and opportunity of education.

In Pride Prejudice (1813), the effect of poor education is shown on marriage when Mr. Bennet expresses how Mrs. Bennet cannot understands his character. "She was a woman of mean understanding, little information, and uncertain temper." (Austen, 1814, p.3). This might justify why Mr. Bennett brought up his five daughters differently to what usually women at that time were expected to learn of skills such as drawing or playing an instrument. Lady Catherine who was astonished that they were not brought up by a governess and did not have the chance to learn such skills, receives an unexpected justification from Elizabeth by saying that: "Compared with some families, I believe we were; but 5 such of us as wished to learn, never wanted the means " (Austen, 1814, p.186). On the tongue of her protagonist, Austen declared that education is more necessary for a woman than just learning a skill for the amusement of others. It's rather better for a woman to amuse her own mind.

Arab World English Journal for Translation \& Literary Studies 
Therefore, Elizabeth identifies herself to Lady Catherine in different situations that she is against the norms of the society, aware of her well-being as a strong woman who is able to make her own decisions. Austen evoked the prejudice of men dominance in her society confronted with impeded resistance by the pride of intelligent women who are aware of this gender hegemony. Mr. Darcy represents the hegemonic masculinity as a product of a patriarchal society limiting activity, mastery, rationality, and competence to men in implication for gender inequality (Hamilton, 2008). her hand:

On the tongue of her protagonist Elizabeth, Austen bursts into Mr. Darcy when he proposes

From the very beginning, from the first moment I may almost say, of my acquaintance with you, your manners impressing me with the fullest belief of your arrogance, your conceit, and your selfish disdain for the feelings of others, were such as to form that ground-work of disapprobation." (Austen, 1813, p. 133).

Similarly, Mr. Thomas imposes his authority on Fanny to marry Henry and sends her back home where she lives in poor circumstances so that she can perceive her marriage to Henry as a good option. Fanny, though, still rejects him in suggestion to refusal of patriarchy. Austen realized the importance of choice for women, in that way her female characters tend to use mating strategies within the limitations of the conservative environment at that era (Kruger, Fisher, Strout, Lewis \& Wehbe, 2014). Mrs. Bennett was very skillful in making those mating strategies in a way to create chances and potentials for her daughters. She forces Jane to ride a horse because she suspects it will rain and this way her daughter will spend more time with $\mathrm{Mr}$. Bingley by staying at Netherfield. This shows that women used all their means to improve their skills pursuing better conditions within the frame of marriage. However, financial security is not granted by a good marriage (Meng \& Omar, 2012). Therefore, Austen's unusual delineation of a good marriage makes her female heroines go beyond any financial utilities that may twist their minds and hearts.

Meanwhile, the way Jane and Elizabeth acted in an adverse manner to their mother's plans ask for a carriage to return home. Their self-esteem makes them unable to bear one more night at Netherfield. Both sisters had the desire to choose what to do on their own regardless of their own mother's endeavors. Swirsky and Angelone (2016) stated that women desire for equity, empowerment, and freedom of choice are significant in decision making. Mrs. Bennett represents the typical woman who implicitly rejects the inequality of rules against women that deprive her daughters from their father's estate to the beneficiary of a distant cousin just because he is a male.

A woman like her with little mindedness tries to gain back her daughters' rights through her own way of mate matching strategies in order to secure them among the gentry class. In contrast to Mrs. Bennett's indirect means focusing on outer matters in pursue to gain a man, the two educated daughters represent the intelligent mentality of modern women who adopt a straightforward approach depending on their inner merits where they do not have to trouble themselves with so many divergent means in order to win the right man. Their means and goals are totally different from common ways of typical women, such as seduction or submission. They do not use their beauty to tempt a wealthy man, neither have they submitted to a suitor against 
their own will. This new direct approach of a man-woman relationship shows that self-confident and self-recognition balance relations to the contrary of the market marriage principles.

In addition, the right man who fits the standards of the English society as a man of wealth is not always the right man. The right man is the one of morals and high intellect and this is the standard for equality. Elizabeth manifested her concept of equality when she cleared to Lady Catharine that she is the right match for Mr. Darcy based on their equality of morals and intellects by stating: "In marrying your nephew, I should not consider myself as quitting that sphere. He is a gentleman; I am a gentleman's daughter; so far we are equal" (Austen, 1813, p.395). This is a bright clue that Austen's heroine represents the modern image of a woman who views herself neither beneath nor above her mate's domain. In other words, Austen ironically criticizes the matter of superiority and inferiority in society especially when it comes to human relations.

\section{Results:}

While doing this research paper, it was realized the massive bulk of studies that have been made investigating Austen's works which reflect the depth and novelty of her work. No wonder that she gained fame till our present time by only six novels. Many researchers questioned the reasons behind the superstardom of Austen like Brownstein, (1988), Scheuermann (2009), and Webber, (2017).

For instance, In Mansfield Park, Austen exploited morality, while in Pride and Prejudice she has tackled gender equality. Austen was a woman-centered writer during the hegemony of a patriarchal society. Her satirical style and educative manner are not the only reasons behind her fame for over 200 decades. She crafted her novels to suit all readers and minds. When first she published Pride and Prejudice it got a high rate of publication because of the ironic style and British humor.

Then, she published Mansfield Park which was intended to be more educative. Austen excelled in creating a combination of her thoughts and works. The perplexity around her fame is due to her genius in creating realistic situations not far from reality in a fictional style that pleased readers since it echoes their experiences and touches their inspirations, especially for women, with the image of the accomplished woman.

One of the good justifications why Austen's novels are considered as masterpieces, is that they have a psychological penetration in the characters' souls and have ironic humor (Михайлусева, 2011). In addition, Austen discussed the common place and domestic life that of much familiarity to her readers. Very similar to the schema theory and the integral schema teaching model specifically. In order to understand the unfamiliar new concepts, it is required that the reader depends on the prior knowledge gained from the surrounding environment. The Schema activation works by signaling the direction for the reader to look for the relevant schema from the memory by some textual stimuli to understand present reading task. (An, 2013).

Arab World English Journal for Translation \& Literary Studies 
The familiarity of the common place, and universal themes like love and marriage in her novels granted a positive intercommunication with the reader. Issues like gender equality, women's education, and individualism unhampered by any rigid or political doctrine at that era. Eventually, Austen succeeded to across her unfamiliar concepts through familiar channels. A scene in Mansfield Park shows the nonsense of rules during the eighteenth and nineteenth centuries when Mrs. Fanny cried out how would the possessions of her husband would turn to a cousin just because he is a male.

Another political scene, that has been discussed extensively and received different interpretations in modern criticism when Miss Fanny wanted to ask Sir Thomas about slaverytrade in Antigua and Edmund encouraged Fanny to question, but she explained why she did not carry on, saying: "And I longed to do it, but there was such a dead silence" (Austen, 1814, p.141) . 'Dead silence' for modern critics implies hidden abuse and horror, or moral indifference from her cousins who do not have the same interests. Other interpretations assumed that no slave master could enjoy being asked about his human possessions (Boulukos, 2006). Such a simple scene entails many different interpretations of the complexity of Austen's work.

Austen was more apt to reason rather than emotion, therefore, with her inventive techniques she exploited love as an indirect tool of empowerment. The demands of the marriage market obliged women to rely on men. The basic needs for food, shelter come at the base of Maslow's hierarchy (1943) of the human needs. Women were stuck for a long time at the bottom of the society due to their dependency on men to provide them with these necessities. Austen connected independency with women financial freedom presenting herself as a writer gaining money to support herself as a single woman. The example of love that she revealed in Pride and Prejudice and Mansfield Park for her heroines proved that love worked as an active agent against the market marriage. Elizabeth and Fanny because of their rational thinking and intelligent love, they exercised power by making their own decisions to choose whom to marry.

The refusal of marriage to Mr. Darcy and Mr. Crawford by Elizabeth and Fanny considered as a feminist triumph since their stand points strike a line over the concept of the marriage market. The leap that women can make if they can be financially independent according to Maslow's, leads to the top of the pyramid of self-esteem and self-actualization. The appeal for gender equality is revealed in Pride and Prejudice through the mutual dependence of women and men on each other. Darcy and Elizabeth experienced making errors and correcting each other. Women's power also is shown to exceed the realm of home in contrast to the convention of the Victorian's era that the women's power are inside their domestic (Shaffer, 1992).

Austen used education as tool of improvement that can make a poor woman an accomplished woman though. Miss Crawford in Mansfield Park thought that she is an accomplished woman due to her gentry's class and intelligence, however, Fanny's improvement through educating herself made her mature and an accomplished woman. In addition to education, Austen as a woman of values asserted that neither a man nor a woman can be privileged for their wealth or education only without good morals. 


\section{Conclusion:}

To conclude, it is demonstrated that Austen in both novels is a renowned female writer whose immensity exists in showing her society from a female perspective. The conclusions of Austen's novel showed self-consciousness that appears her presentation of unfamiliar concepts in familiar contexts. She showed the dominant social norms that often challenge and substitute traditional ideals. Additionally, she substitutes the arbitrary endings of novelist impartiality with consistent evolution of themes and plots. These features are particularly useful in a much-needed revaluation of Mansfield Park and Pride and Prejudice for they validate that it is not the informative work described in conventional criticism. Therefore, Austen's radical conclusion is reliable apparatus for representative, rather than instructive, analysis of themes, society and characters from unfamiliar concepts in familiar context viewpoints. Finally, it is proposed that the two novels are the result of patriarchal society and yet, despite of all the limitations, have earned financial returns, reputation and fame due to the unconventional thoughts of Austen.

\section{About the authors:}

Assia Alhasan is an English Language Instructor at the Institute of Languages in University of Tabuk, Saudi Arabia. She is doing her PhD in English Literature at the Faculty of Modern Languages and Communication in University Putra Malaysia (UPM). Her main interests focus on feminism and gender studies. https://orcid.org/0000-0002-1373-7242

Dr. Noritah Omar is an Associate Professor of Literature and Gender Studies at the Dept. of English at the Faculty of Modern Languages and Communication in University Putra Malaysia. She is the Deputy Director of Putra International Centre. Her Main interests are postcolonial theory and literature, and gender studies.

\section{References}

Alkubaisi, M. H. S. (2020). Jane Austen: Modern Supremacy. Revista de Stiinte Politice, (66),150160

An, S. (2013). Schema Theory in Reading. Theory \& Practice in Language Studies, 3(1), 130-134. Aron, R. (2014). Jane Austen and the European Union on "An Accomplished Young Woman”. Journal of Research in Gender Studies, 4(1), 995-1009.

Asokkumar, V. (2014). Female Psyche and Empowerment of Jane Austen and Lakshmi's Select Novels. International Journal of Research, 1(9), 1276-1282.

Austen, J., \& Jones, V. (2003). Pride and prejudice. London: Penguin Books.

Austen, J., \& Kinsley, J. (2003). Mansfield Park. Oxford: Oxford University Press.

Băniceru, Cristina. (2019). Jane Austen: Glose, înțelesuri, interpretări. Coordonator Mihaela Mudure. Cluj Napoca: Casa Cărții de Știință, 2019, 247p. ISBN: 978-606-17-1175-8.. Gender Studies. 18. 187-193.

Boulukos, G. E. (2006, July). The Politics of Silence:" Mansfield Park" and the Amelioration of Slavery. Novel: A Forum on Fiction, (3), 361-383. Duke University Press.

Brownstein, R. M. (1988). Jane Austen: irony and authority. Women's Studies: An Interdisciplinary Journal, 15(1-3), 57-70. 
Caffrey, M. (1997). Jane Austen's Women: Seeking equity through relationships and gaining individual and social empowerment (Order No. EP21237).

Chandio, R., Fatima, S., \& Soomro, S. (2019). Pride and Prejudice \& Doll's House: A Comparative Feminist Discourse. Language in India, 19(8), 293-304.

Dangel Stasio, Michael J., and Kathryn Duncan (2015). "An Evolutionary Approach to Jane Austen: Prehistoric Preferences "In Pride and Prejudice"." Studies in the Novel 39.2 (2007): 133-146.

Dole, C. M. (2007). Jane Austen and mud: Pride \& Prejudice (2005), British realism, and the heritage film. Persuasions: The Jane Austen Journal On-Line, 27(2).

Evans, M. (1986). Jane Austen's feminism. Women's Studies International Forum, 9(4), 313-321. Pergamon.

Faris Durrani (2019). Austen: Feminist and Revolutionist - An Annotated Bibliography. Georgia Institute of Technology.

Fletcher, A., \& Benveniste, M. (2013). A scientific justification for literature: Jane Austen's free indirect style as ethical tool. Journal of Narrative Theory, 43(1), 1-18.

Fessenbecker, P. (2011). Jane Austen on Love and Pedagogical Power. Studies in English Literature, 1500-1900, 747-763.

Guna, S. P. (2015). The Theme of Love and Marriage in Jane Austen's Novels: Pride and Prejudice and Sense and Sensibility. Language in India, 15(1), 101-117.

Hall, L. A. (2009). Grounding the Figure of the Heroine: The" other Women" in Jane Austen's Novels, (Doctoral dissertation). Available from ProQuest.

Hamilton, S. N. (2008). Constructing Mr. Darcy: Tradition, gender, and silent spaces in Jane Austen's "Pride and Prejudice", (Unpublished Master's Thesis). University of Central Oklahoma, Edmond, Oklahoma.

He, X., \& Liao, L. (2015). Women Consciousness Exploration in Jane Austen and Her Works. Journal of Education and Training Studies, 3(6), 293-297.

Hynes, L. (2017, Jul 15). Why Jane Austen's view of marriage was in its way quite modern, a contract between equals.

Kearney, J. A. (1990). Jane Austen and the Reason-Feeling Debate. Theoria: A Journal of Social and Political Theory, (75), 107-122.

Kestner, J. A. (1994). Jane Austen: Revolutionizing Masculinities. Persuasions, 16, 147-60.

Kruger, D. J., Fisher, M. L., Strout, S. L., Lewis, S., \& Wehbe, M. (2014). Pride and Prejudice or Family and Flirtation? Jane Austen's Depiction of Women's Mating Strategies. Evolutionary Studies in Philosophy and Literature, 38(1), A114-A128.

Knox-Shaw, P. (2004). Jane Austen and the enlightenment. Cambridge University Press.

Lanski, Marghanita (1969). Jane Austen and Her World. London. Thames and Hudson. Print.

Luxemburg, R. (1992). Die russische Revolution. In O. K. Flechtheim (ed.), Politische Schriften (Vol. 3, pp. 106-141). Frankfurt: Europa Verlag Wien.

Marek, M. (2018). Some Thoughts on Michael Chwe's, Jane Austen, Applied Game Theorist". Decyzje, (30), 63-74.

Marzec, J. C. B. (2014). Reading Relationships in Jane Austen's Mansfield Park and Pride and Prejudice, (Unpublished Master's Thesis). University of Windsor, Ontario, Canada.

Marrero, L. D. J. (2013). Courtship and marriage in the work of Jane Austen.

Arab World English Journal for Translation \& Literary Studies

ISSN: 2550-1542 | www.awej-tls.org 
Massiha, L., \& Omar, N. (2013). James Joyce's Father Foreclosure: The Symbolic Order of Language and Social Existence. Editorial Board, 203.

McElligott, E. Jane Austen: Shaping the Standard of Women's Education. MJUR Midwest Journal of Undergraduate Research, 79-98.

Meng, Q., \& Omar, N. (2012). Resistance Against and Collusion with Colonialism: Eileen Chang's Writing and Translation of "Steamed Osmanthus Flower Ah Xiao's Unhappy Autumn". Editorial Board, 563.

Mikhalusieva, V. A. (2011). Jane Austen Life and Creativity.

Moe, M. (2016). Charlotte and Elizabeth: Multiple Modernities in Jane Austen's Pride and Prejudice. ELH, 83(4), 1075-1103.

Михайлусева, В. А. (2011). Jane Austen. Life and Creativity.

Mondadori Simionato, Deborah. (2018). The Real Jane Austen: Austen's Shifting Image. Cadernos do IL. 220.

Nandana, N. G. (2012). Emphasis on Education in Jane Austen's Novels. International Journal of Scientific and Research Publications, 2, 1-3.

Patil, Y. (2014). The Chemistry of Love. International Journal of Scientific \& Engineering Research, 5(4), 1317-1319.

Radu, M. C. (2013).The Female Character in Jane Austen's Novel and in their Screenings.

Samuelian, K. F. (2009). Managing Propriety for the Regency: Jane Austen Reads the Book. Studies in Romanticism, 48(2), 279-297.

Shukurova Nigina Oripovna, Ochilova Mekhriniso Razzokovna, Kadirova Zaynab Bakoyevna, Raupova Nigora Djalalovna (2020). Artistic Embodiment of the Concept of "Pride" in Jane Austen's Novels. Journal of Critical Reviews, 7 (18), 850-853.

Smith, G. (1890). Life of Jane Austen (Vol. 26). London: Walter Scott.

Smith, P. (1994). Mansfield Park and the world stage. Cambridge Quarterly, 23(3), 203-229.

Sundari Guna, (2015) "The theme of love and marriage in Jane Austen novel Pride and Prejudice". www.languageinindia.com. ISSN 1930-2940, Vol. 15:1.

Swirsky, J. M., \& Angelone, D. J. (2016). Equality, empowerment, and choice: what does feminism mean to contemporary women? Journal of Gender Studies, 25(4), 445-460.

Shultz, J., (2018). Feminism and Familiarity: Emily Brontë's Wuthering Heights.

Tauchert, A. (2003). Mary Wollstonecraft and Jane Austen: 'Rape and' Love' as (Feminist) Social Realism and Romance. Women: A Cultural Review, 14(2), 144-158.

Tauchert, A. (2005). Romancing Jane Austen: narrative, realism, and the possibility of a happy ending. Springer.

Trilling, L. (1957). Emma and the legend of Jane Austen. Beyond Culture: Essays on Literature and Learning, 31-55.

Toner, A. (2020). Jane Austen's Style: Narrative Economy and the Novel's Growth. Cambridge: Cambridge University Press.

Webber, M. (2017, Jul 18). Why Jane Austen is for all readers, not just women: The perception of Jane Austen as a "women's writer" is drawn from recent rom-com adaptations of her work, but her books should be enjoyed by everyone, say two literary academics. ABC Premium News. 
AWEJ for Translation \& Literary Studies Volume, 4 Number 4. October 2020

Worsley, L. (2017). Jane Austen at Home: A Biography. St. Martin's Press. Rubin, M. (1988, Feb 21). Jane Austen as a woman of the world Jane Austen her life by Park Honan.

Scheuermann, M. (2009). Reading Jane Austen. Springer.

Sha'bäni, M., Harehdasht, H. A., \& Naseri, F. (2019). A Comparative Study of Plato's and Jane Austen's Concept of Love in Pride and Prejudice. International Journal of Applied Linguistics and English Literature, 8(3), 37-45.

Sultana, K. Z. S. (2012). Feminism in Jane Austen's Pride and Prejudice. Journal of Social Sciences, 1(2), 523-536.

Sunalini, D., \& Kumari, V. N. (2017). Woman Perspective in Jane Austen's Pride and Prejudice. International Peer-Reviewed Open Access Journal, (1). 